\title{
TRIBOMETRY: How is friction research quantified? A review
}

\author{
Miyer Jaiver Valdes ${ }^{*}$, Juan Gonzalo Ardila Marín ${ }^{2}$, M.A. Rodriguez-Cabal ${ }^{3}$ and J.D. Betancur ${ }^{4}$ \\ ${ }^{1,3,4}$ Department of Electromechanics and Mechatronics, Instituto Tecnológico Metropolitano, Medellin, Colombia. \\ ${ }^{2}$ Department of Agricultural Engineering, Universidad Surcolombiana, Neiva, Colombia. \\ ORCIDs: 0000-0002-3407-4636 (Miyer), 0000-0003-4461-7195 (Juan), \\ 0000-0002-6506-3542 (Miguel), 0000-0002-3546-8311 (J.D. Betancur)
}

\begin{abstract}
Friction losses represent $23 \%$ of total annual energy consumption globally, which makes its study essential. For the measurement or prediction of the friction force and the wear rate, tribometry arises in charge of experimentally determining the different values under different configurations. From the tests the coefficient of friction and the diameter of the wear scar of the element are determined, to declare the contact conditions. The purpose of this study was to make a report discriminated test parameters, analysed materials and types of lubricants that are reported in the literature for the different types of tribometers that are described according to recognized classifications. It starts with a conceptual framework on friction, lubrication and wear, then defines tribometry and tribometer, and presents two existing tribometer classifications, that of ASLE and that of Stachowiak, and from there the report of studies carried out with disk tribometers begins. - disc, ring disc, ball - three plates, block - ring, pin - plate, pin - disc, ring - cylinder, and four balls. It is verified that for each tribological pair, and study to be carried out, there is an ideal tribometer that must consider international standards, such as those issued by the different ASTM committees, to guarantee its quality. In most cases tribometers are designed by research institutions, showing that for each special case it is necessary to make modifications to existing designs.
\end{abstract}

Keywords: Tribometer, Tribology, Friction, Wear.

\section{INTRODUCTION}

The phenomena of friction and wear have been extensively studied, from this strategy have been generated that allow them to be controlled or reduced in order to maximize the energy of the systems, guaranteeing their useful life and therefore ensuring the correct operation of the different machines and equipment [1]. According to various studies, energy losses due to friction and wear represent $23 \%$ of total annual energy consumption globally [2], therefore, it is essential to study it in order to achieve more efficient systems. The tribology or study of friction theorizes the different mechanisms of friction and wear and proposes methods of lubrication or other strategies for each tribological system. Since each one present specific need that must be met.

Czichos in [3] defines that the entire experimental field of study in tribology is called "tribometry" and the friction measuring devices are defined as "tribometers". The need arises for the measurement or prediction of the friction force and the wear rate, with tribometry being in charge of, through established regulations [4], experimentally determining the different values under different configurations [5]. In a simulated space, the behaviour that a specific lubricant can have, or predict the behaviour of materials when they are in metal-metal friction. Said tests are carried out by means of tribometers, which are designed in specific ways with the aim of bringing the experimental test closer to the tribological system and / or regimen to be analysed [3]. The measurements of the friction coefficients depend on various mechanical factors such as the type of movement, the value of the applied load, the speed at which the test is run, its duration and, in addition to this, the environmental factors such as the humidity and temperature, which must be controlled in order to achieve a more realistic approach to the model studied. From the tests, the coefficient of friction [6] and the diameter of the wear scar of the element are generally determined, to declare the contact conditions. Additionally, the tribometer used may contain sensors that in turn allow the measurement of vibrations, noise and operating temperature. Finding the limit values that can be reached before the element fails. On the other hand, the characteristics of the material such as its composition and roughness should be considered, from which estimates are made to verify the results found in the tests [3].

Next, a discriminated report is made of the different test parameters, analysed materials and types of lubricants that are reported in the literature for the different types of tribometers that are described according to recognized classifications. The main data reported from the tests are the materials analysed and the type of lubricant, since the type of test differs depending on these two parameters, so that the difference in the main variables used to make the experimental approach can be observed. of the tribological pairs simulated with the real model, reporting the load to which the system will be subjected during the test, the speed of the moving element, the total linear distance travelled, the temperature of the elements before the test and the duration of this. Some directly report the applied force as in other cases the pressure exerted on the elements is mentioned.

\section{THEORETICAL FRAMEWORK}

\section{II.I. Friction}

Friction generates a loss of energy and useful power as it is a force contrary to movement [7], this is affected by various factors such as the finish of the surfaces in contact, the composition of the materials, the dimensional tolerances between friction pairs, the operating temperature of the tribological system, the hardness of the materials and the lubrication used, whether solid or liquid. All these parameters are those that define the coefficient of friction which is different for each class of friction force that occurs [6]. It is presented by the interaction between the two surfaces in contact, so its value 
depends both on the weight of the object and the dynamic forces that occur in relative movement, as on the finish of the surfaces and the type of material found in contact [8].

Static friction occurs when the applied force is not sufficient to deform the ridges of the roughness of the contact surfaces; therefore, the object has no movement [9]. Kinetic friction is a force that appears when one body moves with respect to another, this force varies depending on the coefficient of kinetic friction and the load that tends to join the surfaces. Metal-metal friction occurs when two metal surfaces slide with respect to each other without any type of lubricant to separate them, in most cases it generates failures that can become catastrophic due to the high heat generated by the interaction of the crests of the surfaces, in the machines usually appear at the time of starting and stopping [10]. Solid kinetic friction occurs when starting or stopping in tribological systems in which the lubricant has antiwear additives AW or extreme pressure EP due to the limiting film that this type of compound leaves on the surface [8]. Mixed kinetic friction occurs in friction pairs that are under an elastohydrodynamic EHL lubrication regime, in this type adhesive wear is reduced. Fluid kinetic friction occurs when the two surfaces are separated by the lubricant, this varies depending on the type of lubricant used (mineral, vegetable or synthetic).

\section{II.II. Lubrication}

Due to the impact generated by friction phenomena, it is necessary to include lubrication in maintenance plans, under the concept of achieving increased reliability in equipment and ensuring that all its elements reach their available life. It is for the above that to achieve a successful lubrication it is necessary to know the different regimes that are presented in the machines, which can be analyzed from the Stribeck curve, which establishes a relationship between load, speed and absolute viscosity (Hersey number), with the coefficient of friction between 0 and 1, as shown in Figure 1 [11]. The curve consists of 3 moments, where initially a high coefficient of friction is observed at the time of starting or stopping the machine, where metal-metal or solid friction is present. Following this is the mixed lubrication zone, where EHL lubrication can occur, at this point the speeds are low but the mechanism is under the effect of a high dynamic load [12]. Finally, there is the hydrodynamic zone, where the mechanisms that operate at low dynamic loads, but at high speeds, are located.

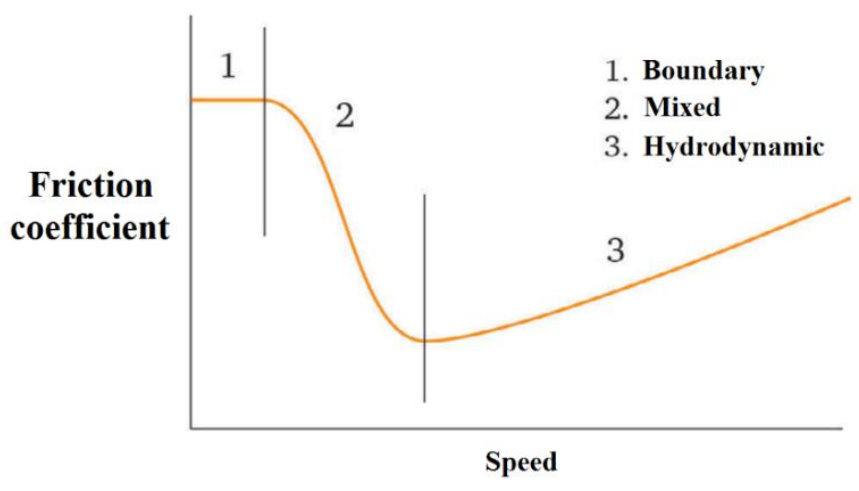

Fig. 1. Stribeck curve. Taken from [11].

\section{II.III. Wear}

Linked to friction is wear, which occurs naturally in the elements of systems in operation over time, this causes the mechanisms to gradually lose tolerances until it ceases to function correctly, that is, they reach their available life [13]. Being a goal of tribology, the reduction of wear must know the different types. Adhesive wear occurs mainly at the time of starting or stopping the machine, during metal-metal friction, the phenomenon occurs when the ridges of the surfaces in contact interact directly with each other, dragging them to the point of material detachment. This type of wear is reduced by means of additives that adhere to the surface firmly. It also occurs in cases where the lubricant used has a lower viscosity than required, due to poor selection or poor maintenance [5]. Surface fatigue wear is caused by cyclic loading. It is present even having the appropriate lubricant, since the effect on the ridges of fluctuating compressive and tension stresses gives rise to the growth of subsurface cracks that ends in the material detachment when reaching the resistance limit [12]. Erosive wear is the product of particles present in the lubricant, which when circulating under high pressure collides with the walls, sweeping the boundary layer and leaving the material unprotected against abrasive wear or other mechanisms, generating loss of material. It cannot be removed because lubricants (including new ones) can have impurities, even though they comply with ISO 4406-99 [13]. Erosion can be caused in turn by cavitation, product of the explosion of bubbles that form in the oil. Abrasive wear, unlike erosive wear, is caused by particles larger than the lubricating film, which generate a detachment of the lubricant boundary layer and therefore of material on the surfaces. Corrosive wear occurs in cases in which the lubricant is contaminated by water, or by acids from its degradation, the effect of its useful life or by contaminated environments [12].

\section{TRIBOMETRY}

Tribological experimental techniques play an important role. Although the experimental determination of the tribological behavior of the materials or lubricants seems easy, since friction and wear are easy to measure, the difficulties are in the interpretation of the results in relation to the various tribotechnical applications of the materials and lubricants. This is a broad topic, from friction and wear measurements, lubricant testing and tribo-technical component evaluation to machine condition monitoring. All critical characteristics of a wear or friction situation can be simulated without difficulty with a properly selected tribometer. Conversely, a poorly selected or poorly designed tribometer can provide false results. Therefore, a deep knowledge of the characteristics of tribometers is essential for any tribological experiment. According to the Society of Tribologists and Lubrication Engineers, there is wide variation in the design and technology of tribometers, there are 234 recognized tribometer designs. Despite the number of designs, the actual range of options for useful experimentation is more limited, most of these designs do not follow the principles of tribological experimentation, the number of tribometers that have been regularly used by research groups is much less [14]. The main reason for the need for a wide range of tribometers is the variety of wear mechanisms that occur in real situations to be simulated, the 
International Journal of Engineering Research and Technology. ISSN 0974-3154, Volume 13, Number 10 (2020), pp. 2596-2610

(C) International Research Publication House. https://dx.doi.org/10.37624/IJERT/13.10.2020.2596-2610

ultimate goal of tribology testing is to understand the performance of materials, surfaces and lubricants in real conditions [15].

\section{TRIBOMETERS}

Figure 2 shows the relevant characteristics and parameters that tribometers should have, the importance of containing various auxiliary equipment that provide movements at the required speed and impose loads and temperatures simulating the actual wear mechanism; This ancillary equipment must also provide lubricant or special gas atmosphere to the test system. The most advanced tribometers are equipped with instruments to measure the coefficient of friction, the friction force, the wear rates, the vibrations, noise in the system and the temperature.

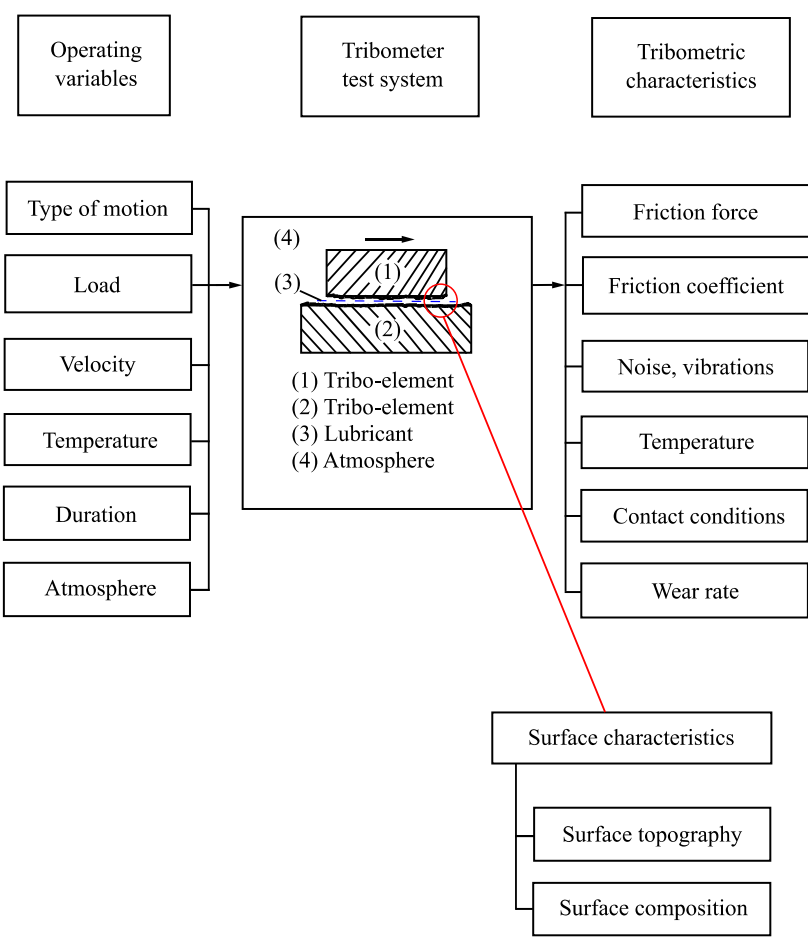

Fig. 2. Characteristics and relevant tribometers parameters.

Taken from [3].

Although there are several tribometers that are described with a wide range of testing capabilities, for example the "universal tribometer", almost known tribometers have a limited range of applications. Each form of wear movement requires a tribometer specially designed to cover a specific range of wear mechanisms or operating conditions and is generally not adequate or inefficient for experimental conditions outside its intended operating range. Tribometers can be classified into groups that are based on wear mechanisms or operating conditions. In a compilation of tribometers edited by the American Society of Lubrication Engineers (ASLE) that includes 234 test kits, the different test tribometers are classified according to their geometry into the following groups [3]:

1) Multiple spheres

2) Crossed cylinders
3) Pin on plate (reciprocating or linear movement)
a) Mobile pin
b) Moving plate
c) Multiple contact

4) Plate on plate (reciprocating or linear movement)

5) Rotating pins on disk

6) Pin on rotating disc

7) Cylinder on cylinder

8) Cylinder or pin on rotating cylinder

9) Rectangular plate on rotating cylinder

10) Disc on disc

11) Multiple specimens

There are other types of classifications such as Stachowiak that in [14] classifies tribometers according to the wear mechanism as shown in Table 1.

Table 1. Classification of tribometers according to the wear mechanism.

\begin{tabular}{|c|c|}
\hline Wear Mechanism & Tribometers \\
\hline \multirow{9}{*}{$\begin{array}{l}\text { Wear due to dry or } \\
\text { partially lubricated } \\
\text { slides }\end{array}$} & Four Ball Tribometer \\
\hline & Falex tribometer \\
\hline & Timken tribometer \\
\hline & Tribometer ball on three plates \\
\hline & Double Disc Tribometer \\
\hline & Ring-on-ring tribometer \\
\hline & Block-on-ring tribometer \\
\hline & Pin-on-disk tribometer \\
\hline & Pin-on-plate tribometer \\
\hline \multirow{5}{*}{$\begin{array}{l}\text { Abrasive, erosive and } \\
\text { cavitation wear }\end{array}$} & Ball Crater Tribometer \\
\hline & 2 Body Abrasive Wear Tribometer \\
\hline & 3 Body Abrasive Wear Tribometer \\
\hline & Erosive Wear Tribometer \\
\hline & Cavitation Wear Tribometer \\
\hline \multirow{4}{*}{$\begin{array}{l}\text { Wear due } \\
\text { environmental } \\
\text { conditions }\end{array}$} & High temperature tribometers \\
\hline & Low temperature tribometers \\
\hline & Tribometers for vacuum operation \\
\hline & $\begin{array}{l}\text { Tribometers for operation in } \\
\text { corrosive liquids. }\end{array}$ \\
\hline \multirow{6}{*}{ Special wear } & Tribometer for corrosion studies \\
\hline & $\begin{array}{l}\text { Tribometer for extremely high slip } \\
\text { speeds - Melt Wear Studies }\end{array}$ \\
\hline & $\begin{array}{l}\text { Tribometer for impact wear } \\
\text { studies }\end{array}$ \\
\hline & $\begin{array}{l}\text { Tribometer for combined } \\
\text { balancing and sliding }\end{array}$ \\
\hline & $\begin{array}{l}\text { Tribometer for on-site studies of } \\
\text { friction and wear }\end{array}$ \\
\hline & Special purpose tribometer \\
\hline \multirow{2}{*}{$\begin{array}{l}\text { Wear due to } \\
\text { lubrication } \\
\text { mechanisms }\end{array}$} & $\begin{array}{l}\text { Tribometer for hydrodynamic } \\
\text { lubrication. }\end{array}$ \\
\hline & $\begin{array}{l}\text { Tribometer for wear and friction } \\
\text { measurements on hydrodynamic } \\
\text { bearings }\end{array}$ \\
\hline
\end{tabular}




\begin{tabular}{|c|c|}
\hline & $\begin{array}{l}\text { Tribometer for vibrations in } \\
\text { hydrodynamic bearings }\end{array}$ \\
\hline & $\begin{array}{l}\text { Tribometer for hydrodynamic } \\
\text { films on bearings }\end{array}$ \\
\hline & $\begin{array}{l}\text { Tribometer for EHL lubrication } \\
\text { studies. }\end{array}$ \\
\hline & $\begin{array}{l}\text { Tribometer for studies of } \\
\text { mechanical properties of adsorbed } \\
\text { films in boundary lubrication - } \\
\text { Surface force apparatus }\end{array}$ \\
\hline & $\begin{array}{l}\text { Tribometer for adhesion between } \\
\text { clean surfaces }\end{array}$ \\
\hline that do not involve & $\begin{array}{l}\text { Tribometers for roughness and } \\
\text { surface deformation }\end{array}$ \\
\hline & $\begin{array}{l}\text { Tribometers for chemistry of clean } \\
\text { or freshly exposed surfaces }\end{array}$ \\
\hline
\end{tabular}

The most commonly used tribometer configurations in the literature are pin on disc, block on ring, ball on 3 plates, four balls, pin on plate or reciprocating, and ring-cylinder piston as shown in Figure 3.

In the pin-on-disk configuration Figure $3 \mathrm{a}$ tests are generally performed following standard test procedures (ASTM G99), the pin remains fixed while the disk rotates around its center axis. The sliding path created in the disc is circular, the rotating disc and the fixed pin generate a tangential or friction force that is measured with the help of load cells and sensors.

Unlike the pin-on-disk configuration, where a unidirectional movement of the pin takes place on a circular track, for the pin- on-plate configuration (Figure 3b) an alternating sliding linear movement is carried out, where the pin moves against the plate in a back and forth motion with linear speed.

In the block-on-ring configuration, a block is pressed against a ring with a designated load as shown in Figure $3 \mathrm{c}$. As the ring rotates at a specific rotational speed, obtaining the coefficient of friction at the contact surface of the block and the ring. This type of tribometer is generally used to measure the coefficient of friction and wear of bearings, rings, etc. In addition, the use of the block-on-ring tribometer has been reported to measure the tribological properties of lubricants.

Another configuration that can be used to estimate the tribological behavior of lubricants is the three-plate ball tribometer. This tribometer consists of a spherical ball and an insert with three plates that can move freely in all directions (Figure 3d). The flexibility of the bottom plates is important to evenly distribute the normal load across the three contact points of the top ball. An uneven distribution of the normal load will lead to erroneous results.

The most common tribometer used to test lubricant performance is the four-ball tribometer. Figure $3 \mathrm{e}$ shows a diagram of the principle of operation of the four-ball tribometer. In this configuration, three balls are held fixed in a ball pot that is filled with the lubricant to be tested. A rotating ball rests on top of the three lower fixed balls. The normal load is applied to the moving ball that rotates at a constant speed during experimentation. An average of the three wear scars is reported as the representative wear parameter of the lubricant.
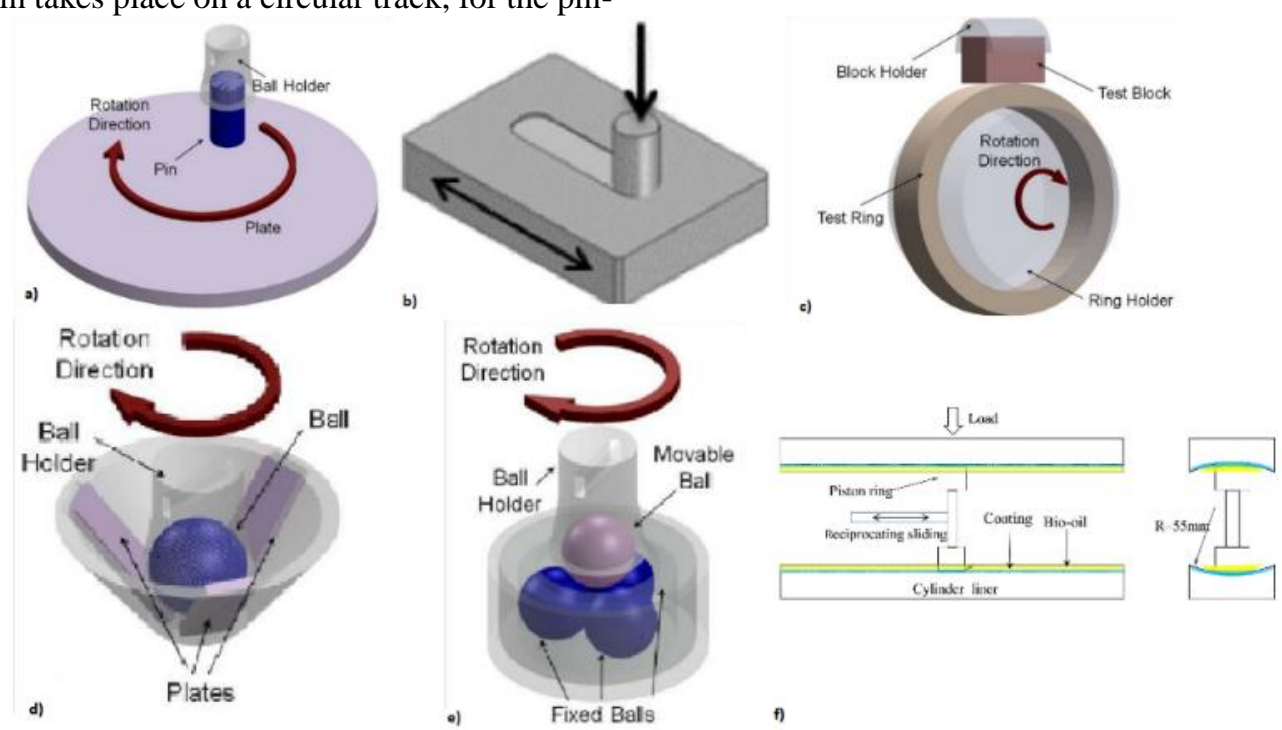

Fig. 3. Schematic representation of different types of tribometers. a) pin on disk [15]. b) pin on plate (reciprocating) [16]. c) block on ring [15]. d) ball on 3 plates [15]. e) four balls [15]. f) ring-cylinder piston [17].

The piston ring-cylinder tribometer, Figure $3 \mathrm{f}$, allows to study the tribological properties of a piston-cylinder system and to measure the friction of the piston ring coating with real components. This resembles the pin-on-plate tribometer in its reciprocating motion, but instead of sliding a pin on a flat plate two curved surfaces slide simulating the interaction of the cylinder with the piston ring and lubricant. In addition, some have an electrical resistance to simulate the temperature reached in the combustion chamber of internal combustion engines.

In this context, it is essential to have some knowledge about the tribological test parameters under which they are being investigated. Table 2 to Table 9 offer an overview of the 
different materials, lubricants, and tribometers that various authors have reported in their investigations. The data depicted in Table 2 to Table 9 provide insight into the range of different experimental parameters that researchers around the world have used in testing tribological performance in their investigations.

\section{IV.I. Double disc tribometer}

In studies reported in the literature, the double disc tribometer is commonly used for the analysis of wear on gears, bearings, rollers, rail wheel systems, among others, where the relative movement between two cylindrical surfaces is presented. As is the case reported by [18], who perform gear tests with the aim of studying the poor lubrication that commonly occurs in this type of system. In Figure 4 it can see a diagram of the tribometer used for this purpose, which allows the variation of the sliding speed in both discs and the variation of the load applied by means of a pneumatic cylinder, where they perform measurements by means of cells load both at the end of the pivot and on the disc located at the base, allowing to control the parameters and achieve measurements that allow finding the friction forces that are presented in the case study analyzed. In addition, it is possible to observe that this tribometer has a device for the lubrication of the elements, with which it is possible to control the lubrication rate, necessary to get closer to the real system to analyze. Table 2 shows other studies in which this type of tribometer is implemented with the parameters used for the specific tests studied by each of the authors.

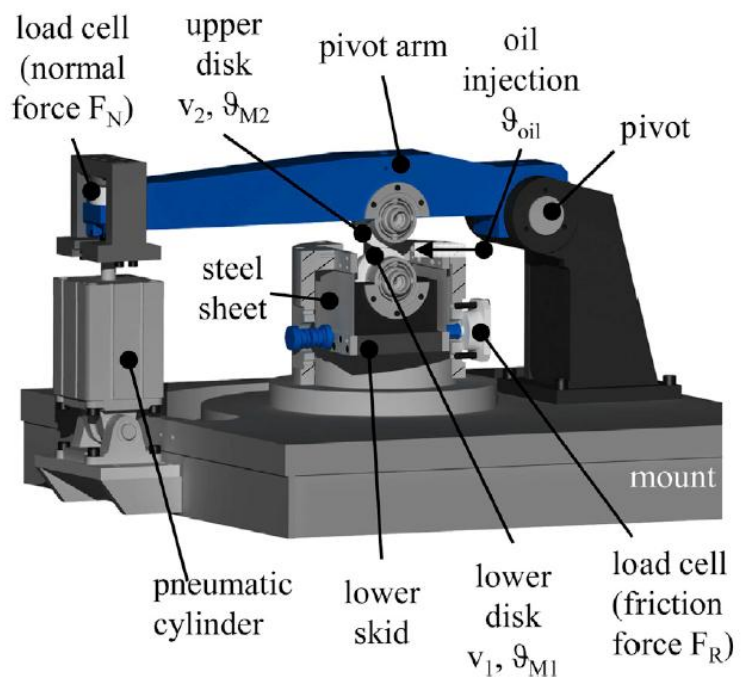

Fig. 4. CAD model of a double disc tribometer. Taken from [18].

Table 2. Details of tribological parameters reported in the literature: Double disc.

\begin{tabular}{|c|c|c|c|c|c|c|c|}
\hline Title & Material & Lubricant & Load & Speed & Distance & Temperature & Duration \\
\hline $\begin{array}{l}\text { Determination of wear } \\
\text { volumes by chromatic } \\
\text { confocal measurements } \\
\text { during twin-disc tests with } \\
\text { cast iron and steel [19] }\end{array}$ & $\begin{array}{l}\text { Discs coated with high } \\
\text { strength steel wire and } \\
\text { cast-iron disks. }\end{array}$ & $\begin{array}{l}\text { Paraffin } \\
\text { Vaseline } \\
\text { free of } \\
\text { additives } \\
\text { (petrolatum) } \\
\end{array}$ & $500,450 \mathrm{~N}$ & $3 \mathrm{~m} / \mathrm{s}$ & $518400 \mathrm{~m}$ & $22{ }^{\circ} \mathrm{C}$ & $48 \mathrm{~h}$ \\
\hline $\begin{array}{l}\text { On the effect of starved } \\
\text { lubrication on } \\
\text { elastohydrodynamic } \\
\text { (EHL) line contacts [18] }\end{array}$ & $\begin{array}{l}\text { Highly charged } \\
\text { elastohydrodynamically } \\
\text { lubricated }\end{array}$ & ISO VG 100 & $1200 \mathrm{~N} / \mathrm{mm}^{2}$ & $2 \mathrm{~m} / \mathrm{s}$ & $21600 \mathrm{~m}$ & & $3 \mathrm{~h}$ \\
\hline $\begin{array}{l}\text { Investigation of anti-wear } \\
\text { performance of } \\
\text { automobile lubricants } \\
\text { using thin layer activation } \\
\text { analysis technique [20] }\end{array}$ & $\begin{array}{l}\text { EN31 steel irradiated } \\
\text { with a } 13 \mathrm{MeV} \text { proton } \\
\text { beam. }\end{array}$ & $\begin{array}{l}\text { SAE 80W90 } \\
\text { grades (L1, L2, } \\
\text { L3, L4) }\end{array}$ & $30,40 \mathrm{kgf}$ & $200 \mathrm{rpm}$ & $5278 \mathrm{~m}$ & $60{ }^{\circ} \mathrm{C}$ & $4 \mathrm{~h}$ \\
\hline $\begin{array}{l}\text { Lifetime prediction of } \\
\text { ceramic components - A } \\
\text { case study on hybrid } \\
\text { rolling contact [21] }\end{array}$ & $\begin{array}{l}\text { Silicon nitride (SN-GP } \\
\text { grade black), 100Cr6 } \\
\text { (AISI 52100) hardened } \\
\text { steel disc crowned } \\
\text { (HRC 64) }\end{array}$ & $\begin{array}{l}\text { SKF TT9 non- } \\
\text { additive } \\
\text { mineral oil }\end{array}$ & $\begin{array}{l}500,850, \\
2500,4150 \mathrm{~N}\end{array}$ & $1500 \mathrm{rpm}$ & - & - & - \\
\hline $\begin{array}{l}\text { Optimization of pre- } \\
\text { conditioned cold work } \\
\text { hardening of steel alloys } \\
\text { for friction and wear } \\
\text { reductions under slip- } \\
\text { rolling contact [22] }\end{array}$ & $\begin{array}{l}\text { 20MnCr5 steel (1.7147, } \\
\text { SAE 4820 / SAE } \\
\text { 5120), Buderus } 9966 \\
\text { Super C steel } \\
\text { (36NiCrMoV1-5-7) } \\
\text { and Aubert \& Duval } \\
\text { V300 silicone-alloyed } \\
\text { spring steel } \\
(45 \text { SiCrMo6, 1.8062)) }\end{array}$ & $\begin{array}{l}\text { BMW FF SAE } \\
0 W-30 \text { VP1 }\end{array}$ & $3.8 \mathrm{GPa}$ & $390 \mathrm{rpm}$ & $1408 \mathrm{~km}$ & $120^{\circ} \mathrm{C}$ & 19 days \\
\hline
\end{tabular}




\section{IV.II. Tribometer ring on ring}

This type of tribometer is implemented to study wear and friction in cylindrical tribological pairs such as camshafts, clutches, bearings, among others. There are two main topologies, in which the contact surface between the disc samples varies, where it can be concentric or tangent. For example [23], using the tribometer shown in Figure 5, authors carried out the study of wear with the objective of analyzing the topography of the surface before and after being subjected to friction, using different methods by laser and 3D scanner. Furthermore, as can be seen, the tribometer was manufactured by the authors, this is common in this type of tests where adaptations are made to existing machines to simulate the specific cases that are to be studied. On the other hand, [24] evaluate the behavior and impact of amorphous hydrogenated carbon coatings applied to aluminum alloys with the aim of reducing friction and controlling wear in scenarios without lubrication that use this type of material, using a tribometer like the one mentioned above. Table 3 presents additional works focused on the Ring on Ring or Ring on Disk tribometer.

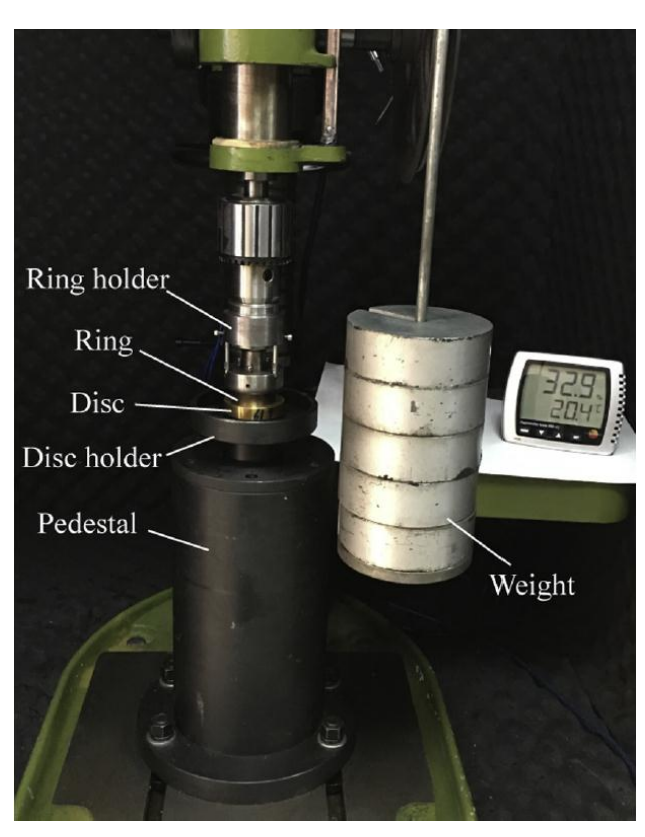

Fig. 5. Ring-disk tribometer photograph. Taken from [23].

Table 3. Details of tribological parameters reported in the literature: Ring on ring.

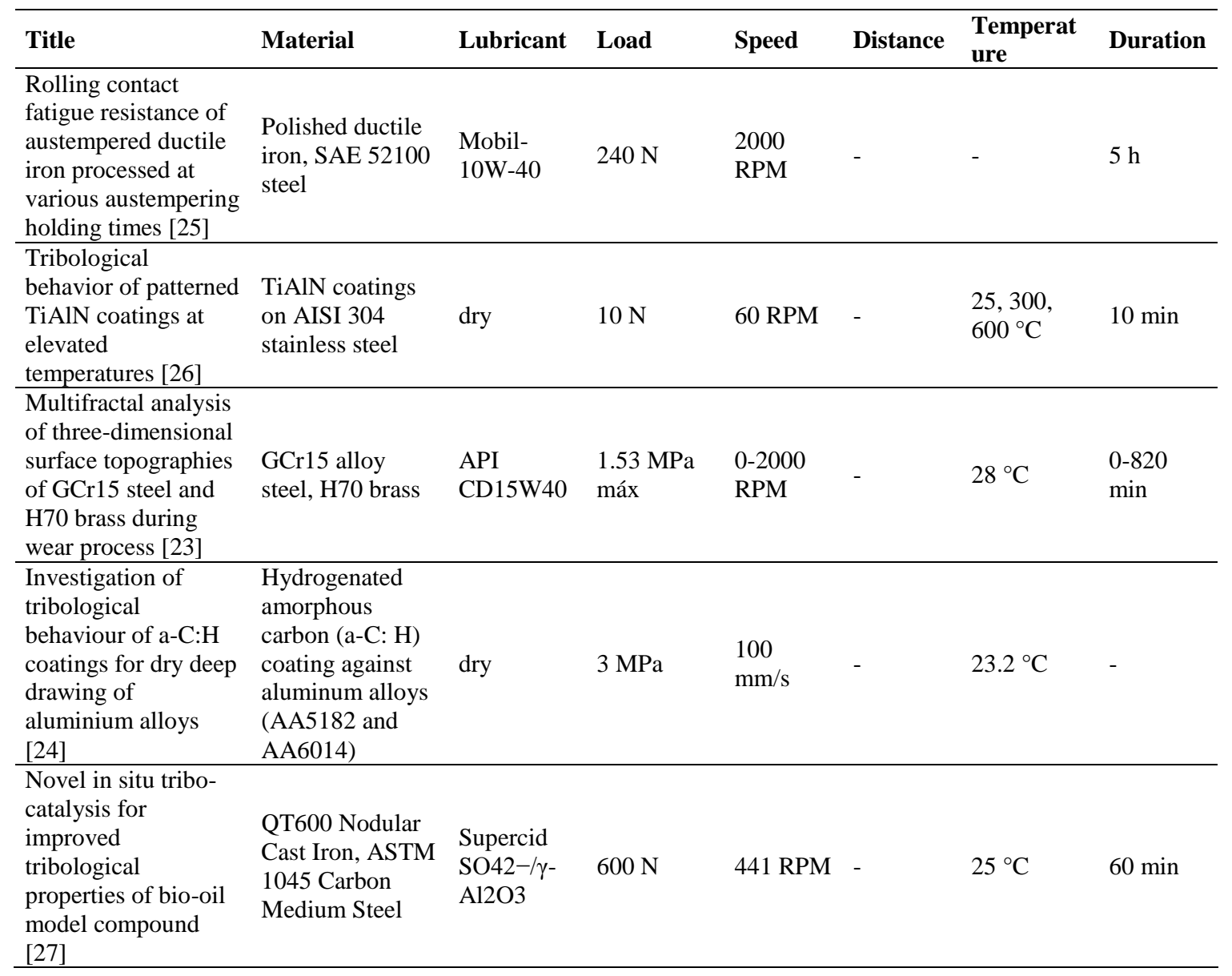


International Journal of Engineering Research and Technology. ISSN 0974-3154, Volume 13, Number 10 (2020), pp. 2596-2610

(C) International Research Publication House. https://dx.doi.org/10.37624/IJERT/13.10.2020.2596-2610

\section{IV.III. Ball tribometer on 3 plates}

The ball tribometer on three plates presented in Figure 6, is commonly used to test new lubricants, in addition, studies have been carried out evaluating wear in surgical materials, as in the case of [28], who carried out research to evaluate materials coated ceramics used in dental implants, where they aimed to find the material with the least wear. For this, the ball tribometer was implemented on three plates because it approximately simulated the phenomenon of friction and wear that dental implants present in real life. On the other hand [29], they presented a study of nanoparticles added to lubricants in order to study the behavior and improvement of water-based nanolubricants, performing tribological tests on a tribometer of this type. Table 4 compiles additional studies where the ball tribometer was used on three plates.

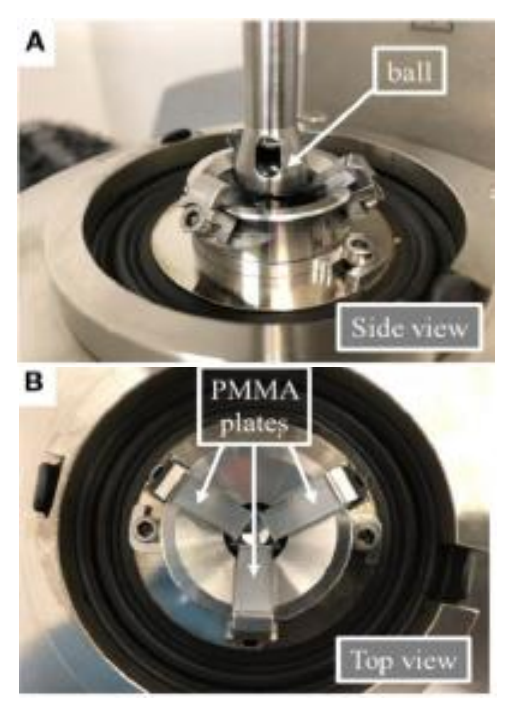

Fig. 6. Ball tribometer photograph - 3 plates. Taken from [30].

Table 4. Details of tribological parameters reported in the literature: Ball on 3 plates.

\begin{tabular}{|c|c|c|c|c|c|c|c|}
\hline Title & Material & Lubricant & Load & Spped & Distance & Temperatute & Duration \\
\hline $\begin{array}{c}\text { Wear of ceramic- } \\
\text { based dental } \\
\text { materials [28] }\end{array}$ & $\begin{array}{c}\text { Ceramic-based } \\
\text { dental materials } \\
(\text { Table } 1)\end{array}$ & dry & $30 \mathrm{~N}$ & $25 \mathrm{RPM}$ & $37 \mathrm{~m}$ & 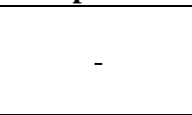 & $60 \mathrm{~min}$ \\
\hline $\begin{array}{c}\text { Tribological } \\
\text { Behavior of } \\
\text { Glycerol/Water- } \\
\text { Based } \\
\text { Magnetorheological } \\
\text { Fluids in PMMA } \\
\text { Point Contacts [30] }\end{array}$ & $\begin{array}{c}\text { Magnetite } \\
\text { particles } \\
\text { synthesized by } \\
\text { partial oxidation } \\
\text { of ferrous } \\
\text { hydroxide with } \\
\text { nitrate. }\end{array}$ & $\begin{array}{c}\text { Dry } \\
\text { magnetite } \\
\text { powder } \\
\text { dispersed } \\
\text { in a } \\
\text { glycerol } \\
\text { mixture }\end{array}$ & $0.5 \mathrm{~N}$ & $\begin{array}{c}0-2800 \\
\text { RPM } \\
(0-1.3 \\
\mathrm{m} / \mathrm{s})\end{array}$ & - & $25^{\circ} \mathrm{C}$ & $2-10 \mathrm{~min}$ \\
\hline $\begin{array}{c}\text { Tribological } \\
\text { Characteristics of } \\
\text { Aqueous Graphene } \\
\text { Oxide, Graphitic } \\
\text { Carbon Nitride, and } \\
\text { Their Mixed } \\
\text { Suspensions [29] }\end{array}$ & $\begin{array}{c}\text { AISI } 52100 \mathrm{Cr} \\
\text { alloy steel and } \\
\text { polished AISI } \\
304 \text { stainless } \\
\text { steel }\end{array}$ & $\begin{array}{c}\text { Water- } \\
\text { based } \\
\text { suspensions } \\
\text { using g- } \\
\text { C3N4, GO } \\
\text { and g- } \\
\text { C3N4 / GO } \\
\text { nano-sheets } \\
\text { as } \\
\text { additives. }\end{array}$ & $\begin{array}{c}10-35 \mathrm{~N} \\
(645-981 \\
\mathrm{MPa})\end{array}$ & $\begin{array}{c}25-125 \\
\mathrm{~mm} / \mathrm{s}\end{array}$ & $7.5 \mathrm{~m}$ & $25^{\circ} \mathrm{C}$ & - \\
\hline $\begin{array}{c}\text { Modification of } \\
\text { Alkali Lignin with } \\
\text { Poly(Ethylene } \\
\text { Glycol) Diglycidyl } \\
\text { Ether to Be Used as } \\
\text { a Thickener in Bio- } \\
\text { Lubricant } \\
\text { Formulations [31] }\end{array}$ & $\begin{array}{l}\text { Poly (ethylene } \\
\text { glycol) } \\
\text { diglycidyl ether } \\
\text { (PEGDE) }\end{array}$ & Beaver oil & $10 \mathrm{~N}$ & $\begin{array}{c}0-1000 \\
\text { RPM }\end{array}$ & - & $25^{\circ} \mathrm{C}$ & - \\
\hline $\begin{array}{l}\text { Role of particulate } \\
\text { concentration in } \\
\text { tooth wear [32] }\end{array}$ & $\begin{array}{l}\text { Silicon nitride } \\
\text { dial, tooth } \\
\text { enamel. }\end{array}$ & dry & $30 \mathrm{~N}$ & $\begin{array}{c}100 \\
\mathrm{~mm} / \mathrm{s}\end{array}$ & $50 \mathrm{~m}$ & - & - \\
\hline
\end{tabular}




\section{IV.IV. Block on ring tribometer}

This type of tribometer has been implemented in research on coatings, polymers and nanolubricants. The type of contact it presents allows evaluating the phenomena of friction and wear between surfaces that are in sliding contact but only one of these present movements. Figure 7 shows a diagram of the tribometer used by [33], who carried out a study of the effect of graphene oxide and hybrid nanoparticles of alumina, as additives in water-based lubricants. The objective was to determine the nano additive that significantly reduced wear on elements subjected to sliding friction. On the other hand [34], they carried out an investigation focused on reducing wear and increasing the coefficient of friction simultaneously by means of coatings, with the aim of prolonging the useful life of automotive brakes, where high friction is required and low wear. The tests were performed on a block-on-ring tribometer. Table 5 compiles additional studies where the block-on-ring tribometer was used.

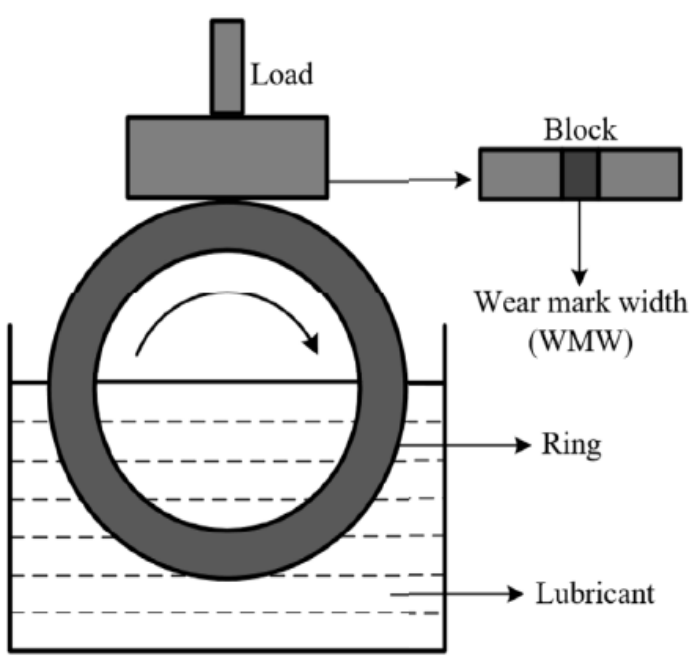

Fig. 7. Schematic representation of the block-ring tribometer. Taken from [33].

Table 5. Details of tribological parameters reported in the literature: Block on ring.

\begin{tabular}{|c|c|c|c|c|c|c|c|}
\hline Title & Material & Lubricant & load & speed & Distance & Temperature & Duration \\
\hline $\begin{array}{l}\text { Correlation of } \\
\text { friction and wear } \\
\text { across length scales } \\
\text { for PEEK sliding } \\
\text { against steel [35] }\end{array}$ & $\begin{array}{l}\text { Poly (Ether } \\
\text { Ether Ketone) } \\
\text { (PEEK, } \\
\text { VESTAKEEP® } \\
\text { 2000G) }\end{array}$ & dry & 1-4 MPa & $\begin{array}{l}0.5-4 \\
\mathrm{M} / \mathrm{s}\end{array}$ & $10 \mathrm{~km}$ & 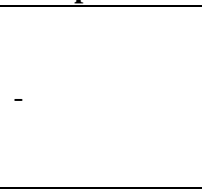 & - \\
\hline $\begin{array}{l}\text { Lubricity of } \\
\text { selected oils in } \\
\text { mixtures with the } \\
\text { refrigerants R452A, } \\
\text { R404A, and R600a } \\
\text { [36] }\end{array}$ & No specified & $\begin{array}{l}\text { POE/R404A, } \\
\text { POE/R452, } \\
\text { MO/R600a }\end{array}$ & $120 \mathrm{~N}$ & $\begin{array}{l}500 \\
\text { RPM }\end{array}$ & - & $23^{\circ} \mathrm{C}$ & $60 \mathrm{~min}$ \\
\hline $\begin{array}{l}\text { Synergistic } \\
\text { tribological } \\
\text { performance of a } \\
\text { water based } \\
\text { lubricant using } \\
\text { graphene oxide and } \\
\text { alumina hybrid } \\
\text { nanoparticles as } \\
\text { additives [33] }\end{array}$ & $\begin{array}{l}\text { AISI } 304 \\
\text { stainless steel, } \\
\text { AISI } 52100 \\
\text { chrome steel }\end{array}$ & $\begin{array}{l}\text { GO-Al2O3 } \\
\text { lubricant }\end{array}$ & $\begin{array}{l}10-30 \mathrm{~N} \\
(70-122 \\
\mathrm{MPa})\end{array}$ & $\begin{array}{l}100-400 \\
\mathrm{~mm} / 2\end{array}$ & $12 \mathrm{~m}$ & $20-25^{\circ} \mathrm{C}$ & - \\
\hline $\begin{array}{l}\text { The effects of } \\
\text { graphene nano- } \\
\text { platelet additions } \\
\text { on the sliding wear } \\
\text { of TiC-Ni3Al } \\
\text { cermets [37] }\end{array}$ & $\begin{array}{l}\text { Cermets de TiC- } \\
\text { Ni3Al, WC-6Co } \\
\text { con polvos }\end{array}$ & dry & $100 \mathrm{~N}$ & $\begin{array}{l}210 \\
\text { RPM }\end{array}$ & $540 \mathrm{~m}$ & - & $45 \mathrm{~min}$ \\
\hline $\begin{array}{l}\text { Simultaneous } \\
\text { increase of friction } \\
\text { coefficient and } \\
\text { wear resistance } \\
\text { through HVOF } \\
\text { sprayed WC-(nano } \\
\text { WC-Co) [34] }\end{array}$ & $\begin{array}{l}\text { fundición } \\
\text { vermicular, } \\
\text { polvo comercial } \\
\text { WC-12Co y } \\
\text { WC-10Co-4Cr }\end{array}$ & dry & $500 \mathrm{~g}$ & $\begin{array}{l}150 \\
\text { RPM }\end{array}$ & - & - & $60 \mathrm{~min}$ \\
\hline
\end{tabular}




\section{IV.V. Pin on Plate Tribometer}

In cases in which the tribological pairs are subjected to reciprocating movements, it is necessary to implement pin-onplate tribometers because it simulates more closely the reality, the phenomena presented in machining, cutting of materials in industry, combustion engines, among others. Such is the case presented by [38], who investigated the tungsten carbide compounds implemented in cutting tools, with the aim of finding the appropriate particle sizes that, when added in the tool forming process, allow reducing the wear and therefore increase the useful life of the tools. In Figure 8, the tribometer used by [16], which is an SRV-4 from Optimol Instruments Prüftechnik $\mathrm{GmbH}$, is shown, with a schematic illustrating the reciprocating movement analyzed and a commercial SRV4® tribometer used by [39] where authors were intended to simulate the wear presented in the metal forming process, where due to high temperatures and forces affected the damaged data will fail, which affects the surface quality and adjustments of the pieces. Table 6 compiles additional studies where the pin-on-plate tribometer was used.
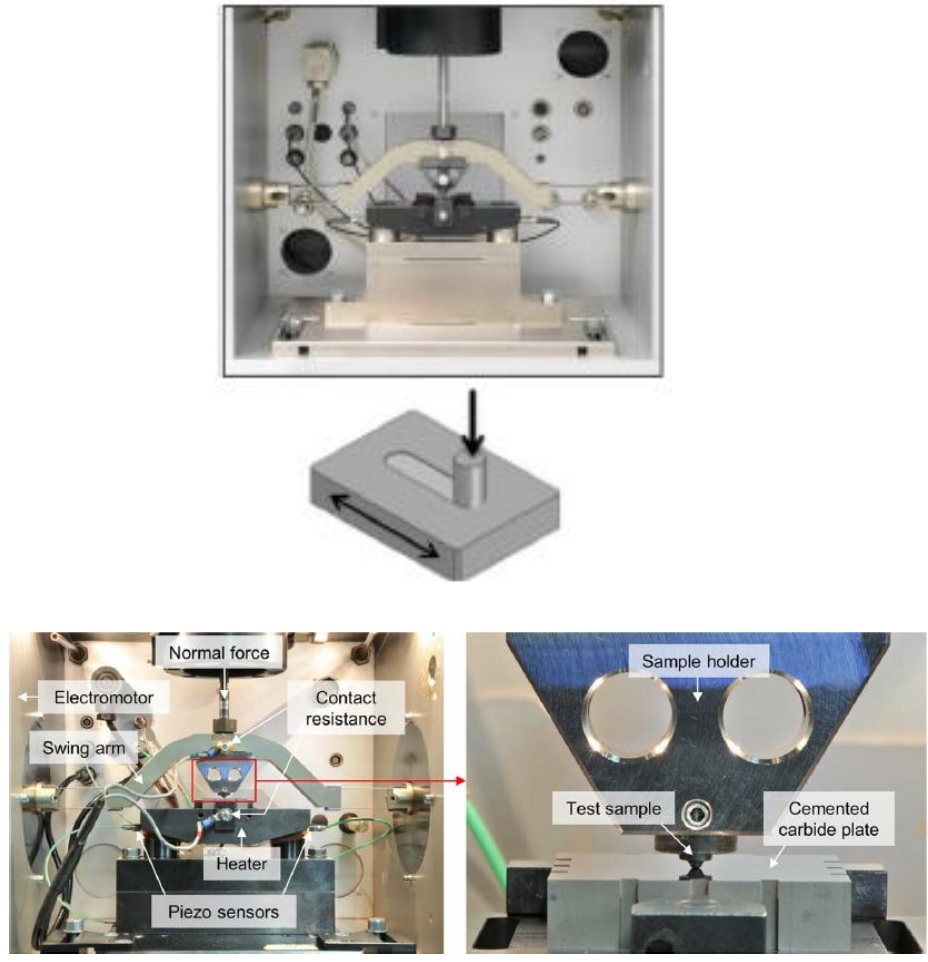

Fig. 8. Photograph of pin-plate tribometer, and schematic representation of the recreated tribological system. Taken from [16] and [39].

Table 6. Details of tribological parameters reported in the literature: Pin on Plate.

\begin{tabular}{|c|c|c|c|c|c|c|c|}
\hline Title & Material & Lubricant & Load & Speed & Distance & Temperature & Duration \\
\hline $\begin{array}{l}\text { Comparison of } \\
\text { unidirectional and } \\
\text { reciprocating } \\
\text { tribometers in } \\
\text { tests with } \\
\text { MoDTC- } \\
\text { containing oils } \\
\text { under boundary } \\
\text { lubrication [16] }\end{array}$ & $\begin{array}{l}\text { AISI 52100, } \\
\text { AISI H13 }\end{array}$ & $\begin{array}{l}\text { SAE 0W- } \\
20\end{array}$ & $35-50 \mathrm{~N}$ & $\begin{array}{l}232 \\
\mathrm{~mm} / \mathrm{s}\end{array}$ & & $40{ }^{\circ} \mathrm{C}$ & $1 \mathrm{~h}$ \\
\hline $\begin{array}{l}\text { Tribological } \\
\text { behavior of cBN- } \\
\text { WC-10Co } \\
\text { composites for } \\
\text { dry reciprocating } \\
\text { sliding wear [38] }\end{array}$ & $\begin{array}{l}\text { CBN-WC- } \\
10 \mathrm{Co} \\
\text { Compounds }\end{array}$ & dry & $30-70 \mathrm{~N}$ & $0.1 \mathrm{~m} / \mathrm{s}$ & & $25^{\circ} \mathrm{C}$ & $30 \mathrm{~min}$ \\
\hline $\begin{array}{l}\text { Reciprocating } \\
\text { sliding wear of the } \\
\text { sintered } 316 \mathrm{~L} \\
\text { stainless steel } \\
\text { with boron } \\
\text { additions [40] }\end{array}$ & $\begin{array}{l}\text { Boron Free } \\
\text { 316L, AISI } \\
316 \mathrm{~L} \\
\text { Austenitic } \\
\text { Stainless Steel, } \\
\text { Alumina } \\
\text { (A12O3) }\end{array}$ & dry & $8 \mathrm{~N}$ & $1.6 \mathrm{~m} / \mathrm{s}$ & $172.8 \mathrm{~m}$ & & $7200 \mathrm{~s}$ \\
\hline $\begin{array}{l}\text { Tribological } \\
\text { investigation of } \\
\text { epoxy/seed } \\
\text { particle composite } \\
\text { obtained from } \\
\text { residues of } \\
\text { processing } \\
\text { Jatropha Curcas } \\
\text { L. fruits [41] }\end{array}$ & $\begin{array}{l}\text { AISI 420C } \\
\text { steel, } \\
\text { composite } \\
\text { material (SC, } \\
\text { S, SKC) }\end{array}$ & dry & $20 \mathrm{~N}$ & & $\begin{array}{l}150 \text { y } 300 \\
m\end{array}$ & $20^{\circ} \mathrm{C}$ & $50 \mathrm{~min}$ \\
\hline
\end{tabular}


International Journal of Engineering Research and Technology. ISSN 0974-3154, Volume 13, Number 10 (2020), pp. 2596-2610

(C) International Research Publication House. https://dx.doi.org/10.37624/IJERT/13.10.2020.2596-2610

\begin{tabular}{|c|c|c|c|c|c|c|c|}
\hline $\begin{array}{l}\text { Comparison of the } \\
\text { wear behaviors of } \\
\text { advanced and } \\
\text { conventional } \\
\text { cemented tungsten } \\
\text { carbides [ } 42 \text { ] }\end{array}$ & $\begin{array}{l}\text { Compound } \\
\text { WC-15\% } \\
\text { Al2O3 } \\
\text { (WA15) and } \\
\text { cemented } \\
\text { carbide WC- } \\
8 \% \text { Co (YG8) }\end{array}$ & dry & $20-80 \mathrm{~N}$ & $0.1 \mathrm{~m} / \mathrm{s}$ & $1500 \mathrm{~m}$ & $20^{\circ} \mathrm{C}$ & $250 \mathrm{~min}$ \\
\hline $\begin{array}{l}\text { Using a standard } \\
\text { pin-on-disc } \\
\text { tribometer to } \\
\text { analyse friction in } \\
\text { a metal forming } \\
\text { process [39] }\end{array}$ & Tube material & $\begin{array}{l}\text { Jabón } \\
\text { fosfato de } \\
\text { zinc y } \\
\text { estearato. }\end{array}$ & $1-2000 \mathrm{~N}$ & $\begin{array}{l}6.3 \\
\mathrm{~mm} / \mathrm{s}\end{array}$ & $800 \mathrm{~mm}$ & $290^{\circ} \mathrm{C}$ & - \\
\hline
\end{tabular}

\section{IV.VI. Pin-on-disk tribometer}

This type of tribometer is one of the most widely used in the fields of tribology, it is used to carry out studies focused on bearings, brake systems, manufacturing industry, train wheel systems, among others. It consists of a pin which, by means of an arm, applies a normal force on a rotating disk, it is tested both in dry conditions and with lubrication. In Figure 9, there is a Pin-Disco tribometer used by [43] where they intended to model the tribometer wear process. On the other hand, [44] they carried out a study of the wear presented in the brakes of trains made of different materials with the aim of determining which one had the longest useful life and correctly fulfilled its function. Table 7 expresses other studies reported in the literature that implemented this type of tribometer.

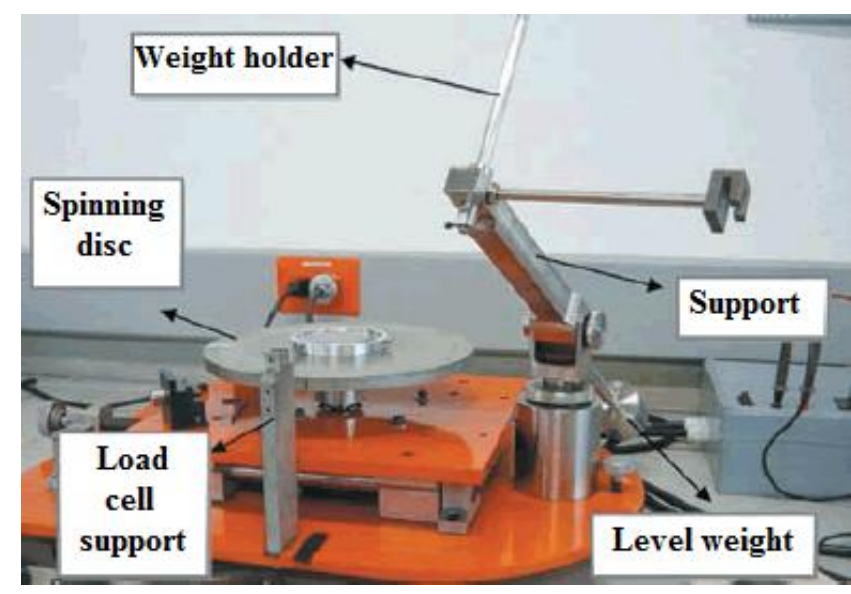

Fig. 9. Pin-disk tribometer photograph. Taken from [43].

Table 7. Details of tribological parameters reported in the literature: Pin on disc.

\begin{tabular}{|c|c|c|c|c|c|c|c|}
\hline Title & Material & Lubricant & Loas & Speed & $\begin{array}{c}\text { Distanc } \\
\mathrm{e}\end{array}$ & $\begin{array}{c}\text { Temperat } \\
\text { ure }\end{array}$ & $\begin{array}{c}\text { Duratio } \\
\text { n }\end{array}$ \\
\hline $\begin{array}{l}\text { Replication of white } \\
\text { etching area } \\
\text { evolution using } \\
\text { novel modified } \\
\text { dynamic load pin- } \\
\text { on-disc tribometer } \\
\text { on bearing steel [45] }\end{array}$ & AISI 52100 & $\begin{array}{l}\text { Hydrogena } \\
\text { ting } \\
\text { lubricant } \\
\text { blend }\end{array}$ & $2.03 \mathrm{GPa}$ & $0.2 \mathrm{~m} / \mathrm{s}$ & - & - & $35-40 \mathrm{~h}$ \\
\hline $\begin{array}{l}\text { A pin-on-disc study } \\
\text { on the tribology of } \\
\text { cast iron, sinter and } \\
\text { composite railway } \\
\text { brake blocks at low } \\
\text { temperatures [44] }\end{array}$ & $\begin{array}{l}\text { Cast, sintered } \\
\text { and composite } \\
\text { iron, R7 railway } \\
\text { wheel. }\end{array}$ & $\begin{array}{c}\text { Worn } \\
\text { graphite }\end{array}$ & $0.8 \mathrm{MPa}$ & $0.45 \mathrm{~m} / \mathrm{s}$ & - & $\begin{array}{l}-30^{\circ}- \\
30^{\circ} \mathrm{C}\end{array}$ & $1200 \mathrm{~s}$ \\
\hline $\begin{array}{c}\text { A pin-on-disc } \\
\text { tribometer study of } \\
\text { disc brake contact } \\
\text { pairs with respect to } \\
\text { wear and airborne } \\
\text { particle emissions } \\
{[46]}\end{array}$ & $\begin{array}{l}\text { Titanium dioxide } \\
\text { (F2), zinc oxide } \\
\text { nanoparticles } \\
\text { (F3), cast iron }\end{array}$ & dry & $0.6 \mathrm{MPa}$ & $850 \mathrm{rpm}$ & $14.1 \mathrm{~km}$ & - & 120 \\
\hline $\begin{array}{l}\text { Temperature field } \\
\text { analysis of pin-on- } \\
\text { disk sliding friction } \\
\text { test [47] }\end{array}$ & $\begin{array}{c}\text { 42CrMo, } \\
\text { 17CrNiMo6 }\end{array}$ & $\begin{array}{c}\text { Lubricating } \\
\text { oil \# } 150\end{array}$ & $\begin{array}{c}200- \\
1000 \mathrm{~N}\end{array}$ & $\begin{array}{c}30-300 \\
\mathrm{~mm} / \mathrm{s}\end{array}$ & - & $20^{\circ} \mathrm{C}$ & - \\
\hline
\end{tabular}


International Journal of Engineering Research and Technology. ISSN 0974-3154, Volume 13, Number 10 (2020), pp. 2596-2610

(C) International Research Publication House. https://dx.doi.org/10.37624/IJERT/13.10.2020.2596-2610

\section{IV.VII. Ring Piston Tribometer - Cylinder}

As its name implies, this tribometer analyzes the phenomenon of friction and wear that occurs in the tribological ring-piston pair (Figure 10), present both in combustion engines and in compressors and pumps. In some cases, the simulation of new lubricants and their impact in reducing wear is intended as proof of the effect of texturing and the coatings applied to the rings, as is the case of [48], who made a coating with nanocomposites to piston rings of a combustion engine, with the aim of improving tribological properties, avoiding premature wear on this type of element. Finding the appropriate thicknesses that presented a higher performance in the system. On the other hand [49] carry out a study on the duration and control of tribofilm formation, and the behavior of common additives in this type of scenario. Table 8 lists a set of investigations that implemented this type of tribometer, where it can see the similarity of the test conditions and how some report the speed of the test or the frequency of the cycle as this is a reciprocating type tribometer.
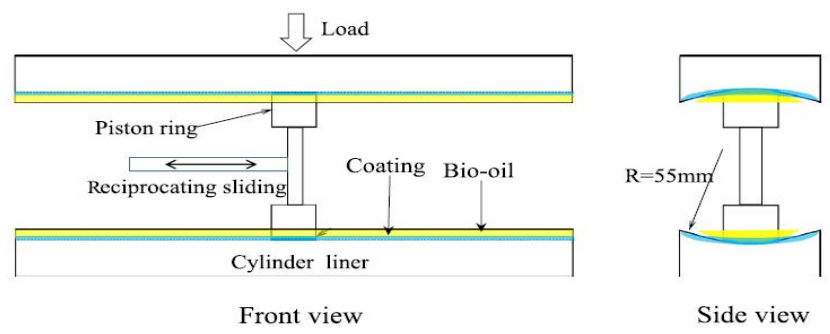

Side view

Fig. 10. Schematic representation of the Piston Ring-Cylinder tribometer. Taken from [17].

Table 8. Details of tribological parameters reported in the literature: Piston Ring-Cylinder.

\begin{tabular}{|c|c|c|c|c|c|c|c|}
\hline Title & Material & Lubricant & Load & speed & Distance & Temperature & Duration \\
\hline $\begin{array}{l}\text { Synergistic effects } \\
\text { of electroless piston } \\
\text { ring coatings and } \\
\text { nano-additives in oil } \\
\text { on the friction and } \\
\text { wear of a piston } \\
\text { ring/cylinder liner } \\
\text { pair [48] }\end{array}$ & Molten iron & $\begin{array}{l}\text { Fe304@MoS2 } \\
\text { nanocomposites }\end{array}$ & $140 \mathrm{~N}$ & $5 \mathrm{~Hz}$ & $80 \mathrm{~mm}$ & $25^{\circ} \mathrm{C}$ & $3 \mathrm{~h}$ \\
\hline $\begin{array}{l}\text { Laser-induced } \\
\text { improvement in } \\
\text { tribological } \\
\text { performances of } \\
\text { surface coatings } \\
\text { with MoS2 } \\
\text { nanosheets and } \\
\text { graphene [17] }\end{array}$ & $\begin{array}{l}\text { Boron cast iron, } \\
\text { ductile iron }\end{array}$ & Bio-oil & $210 \mathrm{~N}$ & $5 \mathrm{~Hz}$ & $80 \mathrm{~mm}$ & $82^{\circ} \mathrm{C}$ & $120 \mathrm{~min}$ \\
\hline $\begin{array}{l}\text { Tribological } \\
\text { assessment of } \\
\text { coated piston ring- } \\
\text { cylinder liner } \\
\text { contacts under bio- } \\
\text { oil lubricated } \\
\text { conditions [50] }\end{array}$ & $\begin{array}{l}\text { Boron cast iron, } \\
\text { ductile iron }\end{array}$ & Bio-oil & $140 \mathrm{~N}$ & $5 \mathrm{~Hz}$ & $80 \mathrm{~mm}$ & $85^{\circ} \mathrm{C}$ & $60 \mathrm{~min}$ \\
\hline $\begin{array}{l}\text { Real time durability } \\
\text { of tribofilms in the } \\
\text { piston ring - } \\
\text { cylinder liner } \\
\text { contact [49] }\end{array}$ & $\begin{array}{l}\text { X90CrMoV18, } \\
\text { gray cast iron }\end{array}$ & $\begin{array}{l}\text { SAE grad 5W- } \\
30\end{array}$ & $200 \mathrm{~N}$ & $6 \mathrm{~Hz}$ & $3 \mathrm{~mm}$ & 20 y $120^{\circ} \mathrm{C}$ & $32 \mathrm{~h}$ \\
\hline $\begin{array}{l}\text { Transient } \\
\text { experimental and } \\
\text { modelling studies of } \\
\text { laser-textured } \\
\text { micro-grooved } \\
\text { surfaces with a } \\
\text { focus on piston-ring } \\
\text { cylinder liner } \\
\text { contacts [51] }\end{array}$ & $100 \mathrm{Cr} 6$ & $5 \mathrm{~W} 30$ y $15 \mathrm{~W} 40$ & $10 \mathrm{~N}$ & $\begin{array}{l}0.0035 \\
\mathrm{~m} / \mathrm{s} \\
0.035 \\
\mathrm{~m} / \mathrm{s} \\
0.35 \mathrm{~m} / \mathrm{s}\end{array}$ & $3.5 \mathrm{~mm}$ & $60^{\circ} \mathrm{C}$ & - \\
\hline
\end{tabular}




\section{IV.VIII. Four balls}

This tribometer is used for the investigation of the tribological properties of lubricants, the test consists of rotating a ball on three others that are fixed on a conical base, applying a force that in most cases increases with each test with the objective of finding out under what conditions the balls join due to the friction forces they experience. Figure 11 shows a schematic of what is the physical principle of this tribometer, which was implemented by [52] who analyzed the friction and wear characteristics of Calophyllum inophyllum biodiesel, demonstrating that it has a lower coefficient of friction and a lower wear than conventional diesel, this due to the concentration of heavy metals that the latter presents. On the other hand, [53] developed a study focused on biodegradable vegetable oils added with reduced graphene oxide (rGO), finding that it is possible to improve the tribological properties of the lubricant base implemented by adding rGO. Table 9 reports other studies found in the literature that implemented this type of tribometer.

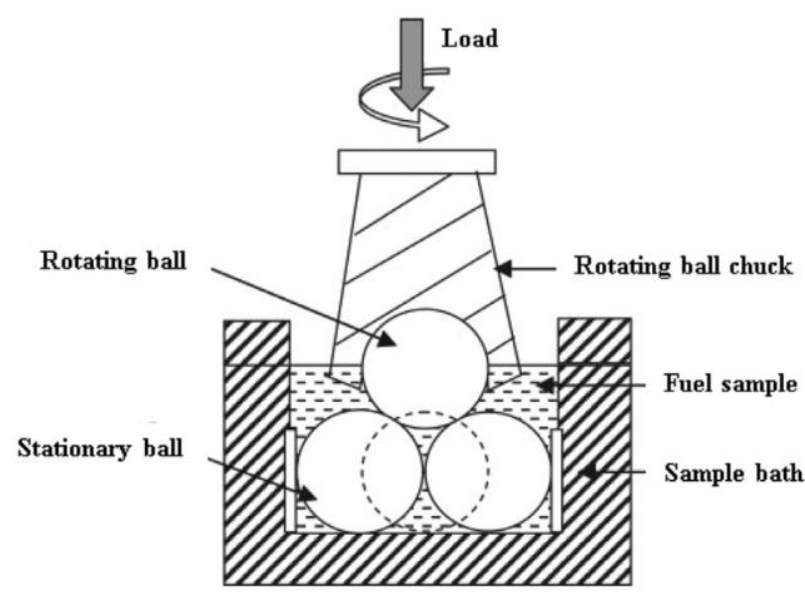

Fig. 11. Schematic representation of the Cuatro Bolas tribometer. Taken from [52].

Table 9. Details of tribological parameters reported in the literature: Four Balls.

\begin{tabular}{|c|c|c|c|c|c|c|c|}
\hline Title & Material & Lubricant & Load & Speed & Distance & $\begin{array}{l}\text { Lubricating } \\
\text { temperature }\end{array}$ & Duration \\
\hline $\begin{array}{l}\text { Tribological } \\
\text { investigation of r-GO } \\
\text { additived biodegradable } \\
\text { cashew nut shells liquid } \\
\text { as an alternative industry } \\
\text { lubricant [53] }\end{array}$ & $\begin{array}{l}\text { AISI } \\
52100\end{array}$ & $\begin{array}{l}\text { cashew shell } \\
\text { liquid }\end{array}$ & $\begin{array}{l}500- \\
1600 \mathrm{~N}\end{array}$ & $\begin{array}{l}1760 \\
\text { RPM }\end{array}$ & & $75^{\circ} \mathrm{C}$ & $3500 \mathrm{~s}$ \\
\hline $\begin{array}{l}\text { Synthesis, } \\
\text { characterisation and } \\
\text { tribological investigation } \\
\text { of vegetable oil-based } \\
\text { pentaerythryl ester as } \\
\text { biodegradable } \\
\text { compressor oil [54] }\end{array}$ & $\begin{array}{l}\text { AISI } \\
\text { E52100 }\end{array}$ & $\begin{array}{l}\text { Rapeseed oil } \\
\text { pentaerythrile } \\
\text { ester (PE) }\end{array}$ & $40 \mathrm{~kg}$ & $\begin{array}{l}1200 \\
\text { RPM }\end{array}$ & & $75^{\circ} \mathrm{C}$ & $1 \mathrm{~h}$ \\
\hline $\begin{array}{l}\text { Improvement in } \\
\text { tribological properties of } \\
\text { lubricating grease with } \\
\text { quartz-enriched rice husk } \\
\text { ash [55] }\end{array}$ & Steel & $\begin{array}{l}\text { NLGI } 3 \text { grade } \\
\text { lithium based } \\
\text { commercial } \\
\text { grease }\end{array}$ & $350 \mathrm{~N}$ & $\begin{array}{l}1650 \\
\text { RPM }\end{array}$ & & $25^{\circ} \mathrm{C}$ & $60 \mathrm{~min}$ \\
\hline $\begin{array}{l}\text { Friction and wear } \\
\text { characteristics of } \\
\text { Calophyllum inophyllum } \\
\text { biodiesel [52] }\end{array}$ & $\begin{array}{l}\text { Carbon- } \\
\text { Chrome } \\
\text { Steel } \\
\text { (SKF) }\end{array}$ & $\begin{array}{l}\text { Biodiesel de } \\
\text { Calophyllum } \\
\text { inophyllum } \\
(\mathrm{CI})\end{array}$ & $\begin{array}{l}40-80 \\
\mathrm{~kg}\end{array}$ & $\begin{array}{l}1800 \\
\text { RPM }\end{array}$ & & $27^{\circ} \mathrm{C}$ & $300 \mathrm{~s}$ \\
\hline \multirow{2}{*}{$\begin{array}{l}\text { The wear resistance of } \\
\text { boride layers measured } \\
\text { by the four-ball test [56] }\end{array}$} & \multirow{2}{*}{$\begin{array}{l}\text { AISI } \\
52100\end{array}$} & $\begin{array}{l}\text { Mobil Delvac } \\
15 \mathrm{~W}-40\end{array}$ & $\begin{array}{l}147- \\
392 \mathrm{~N}\end{array}$ & $\begin{array}{l}1200 \\
\text { RPM }\end{array}$ & & $348 \mathrm{~K}$ & $3600 \mathrm{~s}$ \\
\hline & & dry & $\begin{array}{l}49- \\
147 \mathrm{~N}\end{array}$ & $\begin{array}{l}1200 \\
\text { RPM }\end{array}$ & & - & $150 \mathrm{~s}$ \\
\hline
\end{tabular}

\section{RECOMMENDATIONS}

Carrying out tribological experiments and obtaining valid data is subject to many problems. To obtain significant results, it is necessary to guarantee that the basic conditions for cleaning the samples and the control of the experimental environment are met. Because only a few experimental rigs operate in a completely isolated environment, it is important to check whether unexpected external factors, which can influence friction and wear, are excluded [57]. For this, the ASTM standards that have been designed to guarantee homogeneity in the experimental results must be followed.

Budinski in [58] reports the standards and specifications that have been standardized by ASTM. Some are directed toward an application or material, while others are for general 
evaluation of materials. For example, Committee B-9 standards deal with the types of composite friction materials used for clutches and brakes. The C-5 Committee standard is primarily a checklist and considerations for conducting coefficient of friction tests on carbon-graphite materials. These considerations apply to most friction studies, and this standard is a suitable reference for any beginner in the field of friction.

\section{CONCLUSIONS}

The parameters that affect the friction coefficient and the wear rate in each tribological pair are so diverse and variable that a large number of devices are required to carry out the measurement and investigation of these phenomena, a tribometer should be practically designed for each study. , which makes it difficult to classify and study tribometers. Even so, classifications have been proposed according to the types of relative movement of the frictional torque and additions have been made to the equipment that allows recreating the different conditions that may arise in practice.

Tribometers reported in the literature with various parameters, materials and lubricants investigated by the authors in each of the studies were presented in this review. From what is presented, it is verified that for each tribological pair and study to be carried out, there is an ideal tribometer to carry out the corresponding tests, where international standards must be considered to guarantee their quality.

It is important to highlight that in most cases the tribometers are designed by the different institutions, which shows that for each special case it is necessary to make modifications to the existing designs. On the other hand, commercial tribometers have additional components that are capable of gathering special data such as curves and drag profiles, controlled atmospheres that simulate the existence of pollutants or adverse weather conditions, allowing more specific studies to be carried out.

\section{REFERENCES}

[1] Y. Dong et al., "Friction evolution with transition from commensurate to incommensurate contacts between graphene layers," Tribol. Int., vol. 136, no. March, pp. 259-266, 2019.

[2] K. Holmberg and A. Erdemir, "Influence of tribology on global energy consumption, costs and emissions," Friction, vol. 5, no. 3, pp. 263-284, Sep. 2017.

[3] H. CZICHOS, "Tribometry: Test, Simulation and Control Methods," Tribol. Ser., vol. 1, no. C, pp. 248299, Jan. 1978.

[4] K. G. Budinski, "Laboratory testing methods for solid friction.," Mater. Park. OH ASM Int. 1992., pp. 45-58, 1992.

[5] A. Z. Szeri, "Tribology: Friction, Lubrication, and Wear Hemisphere." Hemisphere Publishing Corp.: Carlsbad, CA, 1980.

[6] J. Hintikka, A. Mäntylä, J. Vaara, T. Frondelius, and A. Lehtovaara, "Stable and unstable friction in fretting contacts," Tribol. Int., vol. 131, no. September 2018, pp. 73-82, 2019.

[7] J. Larsen-Basse, "Introduction to friction.," Mater. Park. OH ASM Int. 1992., pp. 25-26, 1992.

[8] J. Larsen-Basse, "Basic theory of solid friction.," Mater. Park. OH ASM Int. 1992., pp. 27-36, 1992.

[9] H. Czichos, "General Theory of Tribology," in Tribology: A systems approach to the science and technology of friction, lubrication and wear, 1st ed., vol. 1, no. C, Berlin: Elsevier, 1978, pp. 24-44.

[10] M. Urbakh and E. Meyer, "The renaissance of friction," Nat. Mater., vol. 9, p. 8, Jan. 2010.

[11] A. Blazquez de mingo, "Análisis de la lubricación termo-elastohidrodinámica y mixta mediante la aplicación de modelos numéricos," 2016.

[12] P. Albarracin Aguillón, Tribologia y lubricación industrial y automotriz. Talleres Gráficos de Litochoa, 1993.

[13] P. Albarracin Aguillon, Tribologia y Lubricacion, 5th ed. Medellin: Litochoa, 2007.

[14] G. Stachowiak, B. Andrew, and S. Grazyna, "Tribometers," Tribol. Ser., vol. 44, pp. 25-78, Jan. 2004.

[15] P. Gayatri, H. Harish, K. Tapas, and M. N. C., "Nanolubricants Dispersed with Graphene and its Derivatives: An Assessment and Review of the Tribological Performance," Nanoscale, 2019.

[16] R. Balarini, G. A. S. Diniz, F. J. Profito, and R. M. Souza, "Comparison of unidirectional and reciprocating tribometers in tests with MoDTCcontaining oils under boundary lubrication," Tribol. Int., Mar. 2019.

[17] Y. Xu, Q. Zheng, T. You, L. Yao, and X. Hu, "Laserinduced improvement in tribological performances of surface coatings with MoS2 nanosheets and graphene," Surf. Coatings Technol., vol. 358, pp. 353-361, Jan. 2019.

[18] M. Ebner, M. Yilmaz, T. Lohner, K. Michaelis, B.-R. Höhn, and K. Stahl, "On the effect of starved lubrication on elastohydrodynamic (EHL) line contacts," Tribol. Int., vol. 118, pp. 515-523, Feb. 2018

[19] P. Andersson and B. Hemming, "Determination of wear volumes by chromatic confocal measurements during twin-disc tests with cast iron and steel," Wear, vol. 338-339, pp. 95-104, Sep. 2015.

[20] J. Biswal et al., "Investigation of anti-wear performance of automobile lubricants using thin layer activation analysis technique," Nucl. Instruments Methods Phys. Res. Sect. B Beam Interact. with Mater. Atoms, vol. 399, pp. 69-73, May 2017.

[21] I. Khader, S. Rasche, T. Lube, R. Raga, U. Degenhardt, and A. Kailer, "Lifetime prediction of ceramic components - A case study on hybrid rolling contact," Eng. Fract. Mech., vol. 169, pp. 292-308, Jan. 2017.

[22] J. Burbank and M. Woydt, "Optimization of preconditioned cold work hardening of steel alloys for 
friction and wear reductions under slip-rolling contact," Wear, vol. 350-351, pp. 141-154, Mar. 2016.

[23] X. Zuo, Y. Tan, Y. Zhou, H. Zhu, and H. Fang, "Multifractal analysis of three-dimensional surface topographies of GCr15 steel and H70 brass during wear process," Measurement, vol. 125, pp. 196-218, Sep. 2018.

[24] R. Zhao, J. Steiner, K. Andreas, M. Merklein, and S. Tremmel, "Investigation of tribological behaviour of a$\mathrm{C}: \mathrm{H}$ coatings for dry deep drawing of aluminium alloys," Tribol. Int., vol. 118, pp. 484-490, Feb. 2018.

[25] B. Wang, M. He, G. C. Barber, J. D. Schall, C. Tao, and X. Sun, "Rolling contact fatigue resistance of austempered ductile iron processed at various austempering holding times," Wear, vol. 398-399, pp. 41-46, Mar. 2018.

[26] Z. Geng, G. Shi, T. Shao, Y. Liu, D. Duan, and T. Reddyhoff, "Tribological behavior of patterned TiAlN coatings at elevated temperatures," Surf. Coatings Technol., vol. 364, pp. 99-114, Apr. 2019.

[27] Y. Peng, Y. Xu, K. D. Dearn, J. Geng, and X. Hu, "Novel in situ tribo-catalysis for improved tribological properties of bio-oil model compound," Fuel, vol. 212, pp. 546-553, Jan. 2018.

[28] O. Borrero-Lopez, F. Guiberteau, Y. Zhang, and B. R. Lawn, "Wear of ceramic-based dental materials," J. Mech. Behav. Biomed. Mater., vol. 92, pp. 144-151, Apr. 2019.

[29] A. He et al., "Tribological Characteristics of Aqueous Graphene Oxide, Graphitic Carbon Nitride, and Their Mixed Suspensions," Tribol. Lett., vol. 66, no. 1, p. 42, Mar. 2018.

[30] W. O. Rosa, F. Vereda, and J. de Vicente, "Tribological Behavior of Glycerol/Water-Based Magnetorheological Fluids in PMMA Point Contacts," Front. Mater., vol. 6, p. 32, Mar. 2019.

[31] E. Cortés-Triviño et al., "Modification of Alkali Lignin with Poly(Ethylene Glycol) Diglycidyl Ether to Be Used as a Thickener in Bio-Lubricant Formulations," Polymers (Basel)., vol. 10, no. 6, p. 670, Jun. 2018.

[32] O. Borrero-Lopez, P. J. Constantino, and B. R. Lawn, "Role of particulate concentration in tooth wear," $J$. Mech. Behav. Biomed. Mater., vol. 80, pp. 77-80, Apr. 2018.

[33] S. Huang et al., "Synergistic tribological performance of a water based lubricant using graphene oxide and alumina hybrid nanoparticles as additives," Tribol. Int., vol. 135, pp. 170-180, Jul. 2019.

[34] P.-H. Gao et al., "Simultaneous increase of friction coefficient and wear resistance through HVOF sprayed WC-(nano WC-Co)," Surf. Coatings Technol., vol. 363, pp. 379-389, Apr. 2019.

[35] X.-Q. Pei, L. Lin, A. K. Schlarb, and R. Bennewitz, "Correlation of friction and wear across length scales for PEEK sliding against steel," Tribol. Int., vol. 136, pp. 462-468, Aug. 2019.

[36] K. Górny, A. Stachowiak, P. Tyczewski, and W.
Zwierzycki, "Lubricity of selected oils in mixtures with the refrigerants R452A, R404A, and R600a," Tribol. Int., vol. 134, pp. 50-59, Jun. 2019.

[37] M. Gaier, Z. N. Farhat, and K. P. Plucknett, "The effects of graphene nano-platelet additions on the sliding wear of TiC-Ni3Al cermets," Tribol. Int., vol. 130, pp. 119-132, Feb. 2019.

[38] C. Mao et al., "Tribological behavior of cBN-WC10Co composites for dry reciprocating sliding wear," Ceram. Int., vol. 45, no. 5, pp. 6447-6458, Apr. 2019.

[39] I. Velkavrh et al., "Using a standard pin-on-disc tribometer to analyse friction in a metal forming process," Tribol. Int., vol. 114, pp. 418-428, Oct. 2017.

[40] M. Peruzzo, F. L. Serafini, M. F. C. Ordoñez, R. M. Souza, and M. C. M. Farias, "Reciprocating sliding wear of the sintered $316 \mathrm{~L}$ stainless steel with boron additions," Wear, vol. 422-423, pp. 108-118, Mar. 2019.

[41] A. Ruggiero, P. Valášek, M. Müller, and R. D’Amato, "Tribological investigation of epoxy/seed particle composite obtained from residues of processing Jatropha Curcas L. fruits," Compos. Part B Eng., vol. 167, pp. 654-667, Jun. 2019.

[42] Q. Su, S. Zhu, H. Ding, Y. Bai, and P. Di, "Comparison of the wear behaviors of advanced and conventional cemented tungsten carbides," Int. J. Refract. Met. Hard Mater., vol. 79, pp. 18-22, Feb. 2019.

[43] J. S. Rudas F., L. M. Gómez E, and A. Toro, "Modelamiento del proceso de desgaste de un tribómetro pin-disco: Flash temperature y mecanismos de disipación," Iteckne, vol. 10, no. 2, pp. 199-208, 2013.

[44] Y. Lyu, E. Bergseth, J. Wahlström, and U. Olofsson, "A pin-on-disc study on the tribology of cast iron, sinter and composite railway brake blocks at low temperatures," Wear, vol. 424-425, pp. 48-52, Apr. 2019.

[45] K. Sreeraj and P. Ramkumar, "Replication of white etching area evolution using novel modified dynamic load pin-on-disc tribometer on bearing steel," Tribol. Int., vol. 126, pp. 336-343, Oct. 2018.

[46] J. Wahlström, Y. Lyu, V. Matjeka, and A. Söderberg, "A pin-on-disc tribometer study of disc brake contact pairs with respect to wear and airborne particle emissions," Wear, vol. 384-385, pp. 124-130, Aug. 2017.

[47] S. Ying and Y. Yupeng, "Temperature field analysis of pin-on-disk sliding friction test," Int. J. Heat Mass Transf., vol. 107, pp. 339-346, Apr. 2017.

[48] Y. Xu et al., "Synergistic effects of electroless piston ring coatings and nano-additives in oil on the friction and wear of a piston ring/cylinder liner pair," Wear, vol. 422-423, pp. 201-211, Mar. 2019.

[49] S. Spiller, C. Lenauer, T. Wopelka, and M. Jech, "Real time durability of tribofilms in the piston ring cylinder liner contact," Tribol. Int., vol. 113, pp. 92100, Sep. 2017. 
[50] Y. Peng, Y. Xu, J. Geng, K. D. Dearn, and X. Hu, "Tribological assessment of coated piston ring-cylinder liner contacts under bio-oil lubricated conditions," Tribol. Int., vol. 107, pp. 283-293, Mar. 2017.

[51] F. J. Profito, S.-C. Vlădescu, T. Reddyhoff, and D. Dini, "Transient experimental and modelling studies of laser-textured micro-grooved surfaces with a focus on piston-ring cylinder liner contacts," Tribol. Int., vol. 113, pp. 125-136, Sep. 2017.

[52] M. Habibullah et al., "Friction and wear characteristics of Calophyllum inophyllum biodiesel," Ind. Crops Prod., vol. 76, pp. 188-197, Dec. 2015.

[53] S. Bhaumik, V. Paleu, R. Pathak, R. Maggirwar, J. K. Katiyar, and A. K. Sharma, "Tribological investigation of r-GO additived biodegradable cashew nut shells liquid as an alternative industry lubricant," Tribol. Int., vol. 135, pp. 500-509, Jul. 2019.

[54] S. Arumugam, P. Chengareddy, and G. Sriram, "Synthesis, characterisation and tribological investigation of vegetable oil-based pentaerythryl ester as biodegradable compressor oil," Ind. Crops Prod., vol. 123, pp. 617-628, Nov. 2018.

[55] K. Akhtar, H. Khalid, I. Ul Haq, and A. Malik, "Improvement in tribological properties of lubricating grease with quartz-enriched rice husk ash," Tribol. Int., vol. 93, pp. 58-62, Jan. 2016.

[56] E. Garcia-Bustos, M. A. Figueroa-Guadarrama, G. A. Rodríguez-Castro, O. A. Gómez-Vargas, E. A. Gallardo-Hernández, and I. Campos-Silva, "The wear resistance of boride layers measured by the four-ball test," Surf. Coatings Technol., vol. 215, pp. 241-246, Jan. 2013.

[57] G. Stachowiak, B. Andrew, and S. Grazyna, "Sample Preparation and Execution of Tests," Tribol. Ser., vol. 44, pp. 151-164, Jan. 2004.

[58] K. G. Budinski, "Laboratory Testing Methods for Solid Friction," in Friction, Lubrication, and Wear Technology, ASM International, 2017, pp. 44-55. 